Bangladesh J. PI. Breed. Genet., 20(1) : 19-24, 2007

\title{
GENETIC DIVERGENCE IN ASH GOURD (Benincasa hispida Thunb.)
}

\author{
F. Afroze ${ }^{1}$, M. G. Rasul, A. K. M. A Islam, M. A. K. Mian and T. Hossain ${ }^{2}$ \\ Department of Genetics and Plant Breeding \\ Bangabandhu Sheikh Mujibur Rahman Agricultural University \\ Gazipur 1706, Bangladesh
}

\begin{abstract}
Genetic divergence among 46 ash gourd genotypes from different origins was investigated to select the parents for hybridization using Mahalanobis $\mathrm{D}^{2}$ statistics. Though the genotypes grouped into seven clusters, the pattern of distribution of the genotypes into different clusters were random indicating that the geographical isolation was not always related to genetic diversity. Characters like fruit weight, fruits per plant, days to first male flower and nodes for first male flower contributed considerably to the total divergence. Maximum inter-cluster distance between cluster III and IV indicating wide genetic divergence between the genotypes of these two clusters (cluster III and IV followed by cluster IV and VII). However, the intra-cluster distances were smaller than inter-cluster distances. Thus, crossing between the genotypes of these two groups (cluster III and IV) would produce high heterotic progeny and may produce new recombinants with desired traits.
\end{abstract}

Key words: Ash gourd (Benincasa hispida), genetic divergence, $\mathrm{D}^{2}$ statistics

\section{INTRODUCTION}

Ash gourd (Benincasa hispida Thunb.) is a cucurbitaceous vegetable grown widely in summer season in Bangladesh. Bangladesh has been earning a handsome amount of foreign currency by exporting ash gourd to the UK, Pakistan and Middle East (Alamgir, 1981). It becomes available even in the lean period when other vegetables are scarce. Among the cucurbitaceous vegetables and other creepers, ash gourd has shown higher profitability for marginal farmers (Chowdhury, 1993).

Green immature fruits and young twigs of ash gourd are used as vegetable, and mature fruits are also used for preparing candy, sweets and sun dried delicacy called 'kumra bori'. It is a highly nutritive vegetable containing high percentage of digestible protein along with carbohydrates, vitamins and minerals. Though it is a very common crop, it may be mentioned that until to-date there is no released variety of ash gourd with high yield potential and better quality. In spite of its many advantages, research thrust has not been given for the improvement of this vegetable.

\footnotetext{
${ }^{1}$ Scientific Officer (Plant Breeding), Regional Agricultural Research Station, Bangladesh Agricultural Research Institute, Ishurdi, Pabna; ${ }^{2}$ Department of Crop Botany, Bangabandhu Sheikh Mujibur Rahman Agricultural University, Gazipur 1706
} 
Information about the relationship among elite breeding populations and the genetic diversity in available germplasm is important for the optimal design of any breeding program. This helps to choice desirable parents for establishing new breeding populations. Better knowledge on genetic diversity or genetic similarity could help to sustain long term selection gain (Chowdhury et al., 2002).

A previous knowledge of the structure of the genetic diversity within a large collection of germplasm may be of great help to make decisions on management procedures, as well as on breeding strategies to use in current and future breeding programs. According to Sharma and Jana (2002), assessment of genetic variation in a species is a prerequisite for initiating an efficient breeding program, as it provides a basis for tailoring desirable genotypes. Genetically diverse parents are likely to segregate and produce high heterotic crosses. More diverse the parents, greater are the chances of obtaining high heterotic $F_{1}$ s and broad spectrum of variability in segregating generations (Arunachalam, 1981).

\section{MATERIALS AND METHODS}

Forty-six genotypes of indigenous Benincasa hispida of which 45 were collected from the Plant Genetic Resources Centre (PGRC) of Bangladesh Agricultural Research Institute (BARI) and the IPSA-1 genotype from the Department of Horticulture, BSMRAU were studied to measure the diversity among the genotypes at the Field Laboratory, Dept. of Genetics and Plant Breeding, Bangabandhu Sheikh Mujibur Rahman Agricultural University (BSMRAU), Gazipur. The experiment was laid out in a randomized complete block design with three replications during March 2005 to August 2005. The experimental field was divided into three blocks and blocks were subdivided into 46 plots where genotypes were randomly assigned. The unit plot was $6 \mathrm{~m}$ $\times 4 \mathrm{~m}$ in size having $0.5 \mathrm{~m}$ wide drains between two adjacent beds and $1 \mathrm{~m}$ wide drain surrounding the entire experimental field for proper drainage. Pits were prepared in the raised beds. Pit size was dug at a spacing of $(2 \times 2) \mathrm{m}^{2}$. Recommended agronomic practices were followed to raise a good crop.

The data on 18 quantitative characters viz., leaf lobe (grading 1, $2 \& 3$ ), leaf breadth $(\mathrm{cm})$, leaf length $(\mathrm{cm})$, petiole length $(\mathrm{cm})$, internode length $(\mathrm{cm})$, days to first male flower, days to first female flower, nodes for first male flower, nodes for first female flower, fruit length $(\mathrm{cm})$, fruit width $(\mathrm{cm})$, fruit weight $(\mathrm{kg})$, fruit set habit, fruits per plant, seeds per fruit, 100 seed weight $(\mathrm{g})$, vine length $(\mathrm{cm})$ and yield per plant $(\mathrm{kg})$ were recorded on each genotype. Mean data for each character was subjected to multivariate analysis viz, Principal Component Analysis (PCA), Principal Coordinate Analysis (PCO), Canonical Variate Analysis (CVA) and Cluster Analysis (CLSA) using GENSTAT 513 (Mahalanobis, 1936; Jager et al., 1983 and Digby et al., 1989).

\section{RESULTS AND DISCUSSION}

Analysis of variance exhibited significant differences among the genotypes under study indicating notable genetic variability among the 46 genotypes. The $\mathrm{D}^{2}$ value varied widely and principal component scores also revealed a good degree of genetic diversity among the genotypes. 


\section{Cluster analysis}

By application of non-hierarchical clustering using covariance matrix, 46 genotypes were grouped into seven different clusters (Fig.1). Cluster II comprised of maximum number of genotypes followed by cluster VI, VII, I, V, III and IV, respectively. The clustering pattern of the genotypes under this study revealed that the genotypes collected from the same district were grouped into different clusters. As for example, the genotypes of Chittagong district were grouped into five clusters in spite of being collected from the same district. Similar opinions were given by Masud et al. (1995) in pumpkin, Mannan et al. (1992) in pani kachu and Singh and Singh (1979) in okra. It indicates that geographic diversity is not always related to genetic diversity and, therefore, it is not adequate as an index of genetic diversity. Murthy and Anand (1966) stated that genetic drift and selection in different environment could cause greater diversity than geographic distance.

\section{Table 1. Distribution of $\mathbf{4 6}$ ash gourd genotypes in seven different clusters}

\begin{tabular}{|c|c|c|}
\hline Cluster & $\begin{array}{c}\text { No of } \\
\text { genotypes }\end{array}$ & Genotypes with original place of collection \\
\hline I & 5 & $\begin{array}{l}\text { BAg } 12 \text { (Tangail), BAg 24 (Kushtia), } \quad \text { BAg } 25 \text { (Kushtia), } \\
\text { (Chittagong), BAg 51(Chittagong). }\end{array}$ \\
\hline II & 14 & $\begin{array}{l}\text { BAg } 04 \text { (Pabna), BAg } 09 \text { (Natore), BAg } 13 \text { (Tangail), BAg } 14 \text { (Tangail), } \\
\text { BAg 26 (Kushtia), BAg 27(Jessore), BAg } 39 \text { (Chittagong), BAg } 41 \\
\text { (Chittagong), BAg 43 (Chittagong), BAg } 45 \text { (Chittagong), BAg } 46 \\
\text { (Chittagong), BAg } 50 \text { (Chittagong). BAg } 52 \text { (Chittagong), IPSA-1(Gazipur). }\end{array}$ \\
\hline III & 1 & BAg 29 (Faridpur) \\
\hline IV & 1 & BAg 19 (Magura) \\
\hline $\mathrm{V}$ & 4 & $\begin{array}{l}\text { BAg } 21 \text { (Noabganj), BAg } 32 \text { (Chittagong), BAg } 36 \text { (Chittagong), BAg } 47 \\
\text { (Chittagong) }\end{array}$ \\
\hline VI & 12 & 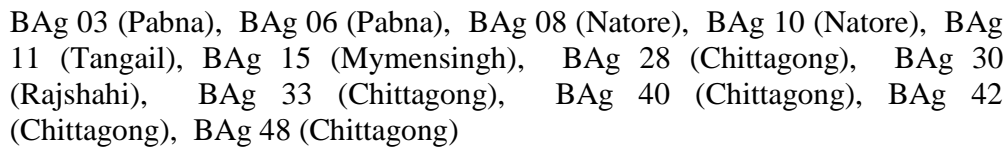 \\
\hline VII & 9 & $\begin{array}{l}\text { BAg } 01 \text { (Kurigram), BAg } 02 \text { (Rangpur), BAg } 05 \text { (Pabna), BAg } 07 \text { (Natore), } \\
\text { BAg } 20 \text { (Naogaon), BAg } 22 \text { (Sherpur), BAg } 23 \text { (Kushtia), BAg } 31 \\
\text { (Rajshahi), BAg } 35 \text { (Chittagong) }\end{array}$ \\
\hline
\end{tabular}

\section{Canonical variate analysis}

The inter-cluster distances were larger than the intra-cluster distances. Higher inter-cluster distance was observed between clusters IV and cluster III, followed by IV and VII, IV and V, IV and VI. The lowest inter-cluster distance was observed between clusters VI and VII followed by VI and II, V and VI in ascending order, suggesting a close relationship among these three clusters (Table 2). 
Table 2. Average intra and inter cluster distances $\left(D^{2}\right)$ for 46 ash gourd genotypes

\begin{tabular}{lrrrrrrr}
\hline Cluster & \multicolumn{1}{r}{ I } & II & III & IV & V & VI & VII \\
\hline I & $\mathbf{1 . 6 4 5}$ & & & & & & \\
II & 8.72 & $\mathbf{1 . 4 3 9}$ & & & & & \\
III & 32.55 & 24.38 & $\mathbf{0 . 0 0}$ & & & & \\
IV & 22.95 & 30.89 & 54.77 & $\mathbf{0 . 0 0}$ & & & \\
V & 14.07 & 6.85 & 19.27 & 36.14 & $\mathbf{1 . 5 9 1}$ & & \\
VI & 13.01 & 4.56 & 20.35 & 35.13 & 5.22 & $\mathbf{1 . 3 9 4}$ & \\
VII & 15.03 & 6.88 & 18.41 & 37.32 & 5.87 & 3.27 & $\mathbf{1 . 7 3 2}$ \\
\hline
\end{tabular}

Genotypes from the distant clusters if involved in hybridization, may give a wide spectrum of segregating population, as genetic variation was very distinct among the groups. Similar reports were also made by Bansal et al. (1999), Mokate et al. (1998), Singh et al. (1996). In this study it was observed that the genotypes of cluster III and IV were highly diverged. So those would be more stable. The genotypes of the distant clusters could be used in crossing programs for obtaining wide range of variation among the segregants.

\section{Cluster mean values}

The cluster mean values were found more or less similar in leaf lobe (grade), internode length $(\mathrm{cm})$, nodes for first male flower and nodes for first female flower. The maximum range of variability was recorded for seeds per fruit among all the characters in seven clusters. Cluster IV and I included mainly early flowering (both male and female) genotypes whereas cluster III included late flowering genotypes.

Table 3. Cluster means for 18 characters of $\mathbf{4 6}$ indigenous ash gourd genotypes

\begin{tabular}{lcc|c|c|c|c|c}
\hline Characters & I & II & III & IV & V & VI & VII \\
\hline Leaf lobe $($ grade) & 1.60 & 1.88 & 2.00 & 2.00 & 1.50 & 1.44 & 1.74 \\
Leaf breadth $(\mathrm{cm})$ & 15.36 & 16.74 & 18.00 & 15.33 & 18.56 & 18.00 & 16.13 \\
Leaf length $(\mathrm{cm})$ & 12.77 & 13.12 & 15.00 & 11.00 & 13.67 & 13.35 & 12.37 \\
Petiole length $(\mathrm{cm})$ & 10.68 & 13.13 & 12.00 & 9.50 & 13.11 & 12.79 & 10.94 \\
Internode length $(\mathrm{cm})$ & 12.13 & 12.13 & 12.67 & 12.00 & 12.42 & 12.04 & 10.78 \\
Days to $1^{\text {st }}$ male flower & 54.93 & 55.43 & 59.00 & 53.00 & 55.09 & 55.72 & 57.19 \\
Days to $1^{\text {st }}$ female flower & 66.33 & 66.17 & 68.67 & 64.33 & 66.34 & 66.67 & 66.93 \\
Nodes for 1 $1^{\text {st }}$ male flower & 28.20 & 28.35 & 27.33 & 28.67 & 28.41 & 28.47 & 28.85 \\
Nodes for 1 $1^{\text {st }}$ female flower & 33.87 & 33.62 & 34.00 & 33.00 & 33.92 & 33.83 & 33.96 \\
Vine length $(\mathrm{cm})$ & 313.15 & 315.73 & 351.50 & 302.73 & 349.06 & 311.59 & 310.40 \\
Fruit length $(\mathrm{cm})$ & 25.93 & 28.24 & 27.00 & 29.33 & 26.41 & 28.00 & 25.33 \\
Fruit width $(\mathrm{cm})$ & 47.93 & 50.86 & 45.00 & 51.67 & 53.75 & 50.80 & 48.56 \\
Fruit weight $(\mathrm{kg})$ & 2.95 & 3.59 & 2.77 & 3.97 & 3.67 & 3.52 & 3.41 \\
Fruit set habit & 4.73 & 3.48 & 3.00 & 4.33 & 4.67 & 3.39 & 3.96 \\
Fruits per plant & 4.00 & 2.64 & 2.33 & 4.67 & 3.83 & 2.64 & 3.26 \\
Seeds per fruit & 451.60 & 381.62 & 194.33 & 651.67 & 348.92 & 343.92 & 321.19 \\
100 seed weight $(\mathrm{g})$ & 5.04 & 5.21 & 2.90 & 3.30 & 4.17 & 4.78 & 4.76 \\
Yield per plant $(\mathrm{kg})$ & 11.87 & 9.47 & 6.47 & 18.57 & 14.14 & 9.40 & 10.58 \\
\hline
\end{tabular}


Cluster I was also important for fruits per plant and yield per plant. Moreover, genotypes of cluster III were important for less seeded fruits. Genotypes of cluster V were important for maximum leaf breadth. To develop high yielding varieties, genotypes of these groups can be used in hybridization programs.

\section{Contribution of characters toward divergence of the genotypes}

The PCA revealed that in vector $1\left(Z_{1}\right)$ the important characters responsible for genetic divergence in the major axis of differentiation were fruit weight, days to first male flower, days to first female flower, fruit length, leaf breadth, nodes for first male flower, vine length and fruit setting habit. In vector II $\left(\mathrm{Z}_{2}\right)$, which was the second axis of differentiation, the responsible characters were petiole length, days to first male flower, nodes for first male flower, fruit width and fruit weight. The role of fruit weight, days to first male flower, nodes for first male flower characters for both the vectors were positive across two axis indicating the important components of genetic divergence in these materials.

Table 3. Latent vectors for 18 characters of $\mathbf{4 6}$ local ash gourd genotypes

\begin{tabular}{lc|c|l|c|c}
\hline Characters & Vector & Vector & Characters & Vector & Vector \\
& $\mathbf{1}$ & $\mathbf{2}$ & & $\mathbf{1}$ & $\mathbf{2}$ \\
\hline Leaf lobe $($ grade) & -0.06 & 0.07 & Vine length $(\mathrm{cm})$ & 0.04 & -0.11 \\
Leaf breadth $(\mathrm{cm})$ & 0.11 & -0.02 & Fruit length $(\mathrm{cm})$ & 0.17 & -0.02 \\
Leaf length $(\mathrm{cm})$ & 0.08 & -0.41 & Fruit width $(\mathrm{cm})$ & -0.14 & 0.07 \\
Petiole length $(\mathrm{cm})$ & -0.03 & 0.10 & Fruit weight $(\mathrm{Kg})$ & 1.04 & 1.30 \\
Internode length $(\mathrm{cm})$ & -0.03 & -0.19 & Fruit set habit & 0.73 & -0.76 \\
Days to $1^{\text {st }}$ male flower & 0.05 & 0.10 & Fruits per plant & -0.58 & 1.64 \\
Days to $1^{\text {st }}$ female flower & 0.46 & -0.13 & Seeds per fruit & -0.11 & -0.00 \\
Nodes for 1 $1^{\text {st }}$ male flower & 0.04 & 0.10 & 100 seed weight $(\mathrm{g})$ & -0.34 & -0.09 \\
Nodes for 1 $1^{\text {st }}$ female flower & -0.16 & -0.13 & Yield per plant $(\mathrm{kg})$ & -0.04 & -0.53 \\
\hline
\end{tabular}

From the above results, it appeared that contribution of fruit weight was the highest followed by fruits per plant to the total divergence in ash gourd. Vector 1 obtained from PCA expressed that fruit weight, fruit set habit and days to first female flower were major characters that contribute to genetic divergence, which was the reflection of first axis of differentiation. In vector 2 , fruits per plant and fruit weight played their role on genetic divergence. Other characters had minor role in determining genetic divergence. Mathew et al. (1986) found that the character, fruits per plant, contributed maximum to total divergence $(80 \%)$ in five botanical varieties of Cucumis melo. Seeds per fruit did not contribute to the total divergence.

The crosses involving parents belonging to the maximum divergent clusters were expected to manifest maximum heterosis and also wide genetic variability. Genotypes included in cluster IV was important for early flowering, fruits per plant and yield per plant; cluster III; for maximum leaf length and cluster V for maximum leaf breadth, respectively. Considering cluster distance and cluster mean value, the genotype(s) BAg 19 from cluster IV, BAg 29 from cluster III, BAg 21, BAg 32, BAg 36 and BAg 47 may be considered better parents for future hybridization program in ash gourd. 


\section{REFERENCES}

Alamgir, M. 1981. Export potential of non-traditional agricultural products (Bangladesh). Bangladesh Quarterly. (Mar.1981). V.1 (3): 12-13.

Arunachalam, V. 1981. Genetic distances in plant breeding. Indian J. Genet., 41: 226236.

Bansal, U. K., R. G. Saini, N. S. Rani and A. Kaur. 1999. Genetic divergence in quality rice. Oryza. 36 (1): 20-23.

Chowdhury, M. A., V. Vandenberg and T. Warkentin. 2002. Cultivar identification and genetic relationship among selected breeding lines and cultivars in chick pea (Cicer arietinum L). Euphytica. 127(3): 317-325.

Chowdhury, M. K. 1993. Homestead vegetable production technology for different agroclimatic zones of Bangladesh. In: Intensive Vegetable Growing and Its Utilization. A compilation of lecture matrials of a training course held in BARI, Joydebpur, Gazipur, Bangladesh. 22-25 Nov. 1993. p. 27.

Digby, P., N. Galway and P. Lane. 1989. GENSTAT 5: A Second Course. Oxford Science Publications, Oxford. pp. 103-108.

Jager, M., D. G. Jones and E. Griffiths. 1983. Components of partial resistance of wheat seedlings to Septiria nodorum. Euphytica. 32: 575-58.

Mahalanobis, P. C. 1936. On the generalized distance in statistics. Proc. Natl. Inst. Sci., India. 2:49-55.

Mannan, M. A. 1992. Studies on variability, genetic parameters and correlation in bitter gourd. M. Sc. (Ag.) Thesis, Dept. of Genetics and Plant Breeding, Bangladesh Agricultural University, Mymensingh, Bangladesh.

Masud, M. A. T., M. A. Chowdhury, M. A. Hossain and S. M. M. Hossain. 1995. Multivariate analysis of pumpkin. Bangladesh J. Pl. Breed. Genet. 8(1): 45-50.

Mathew, S. M., P. K. Gopalalrishan and K. V. Peter. 1986. Genetic distance among five botanical varieties of Cucumis melo. Agric. Res. J. Kerala 24(2): 195-196.

Mokate, A. S., S. S. Mehetre, V. W. Bendale and S. P. Birari. 1998. Genetic divergence in rice. Advances Plant Sci. 11(2): 197-198.

Murthy, B. R. and I. J. Anand. 1966. Combining ability and genetic diversity in some varieties of Linium Usitatissimum. Indian J. Genet. Pl. Breed. 26 (1): 21-36.

Sharma. T. R and S. Jana. 2002. RAPD variation in Fagopyrum tataricum Gaertn accessions from China and the Himalayan region. Euphytica. 127 (3) 327-333.

Singh, A. K., S. B. Singh and S. M. Singh. 1996. Genetic divergence in scented and fine genotypes of rice ( Oryza sativa L.). Ann. Agril. Res. 17 (2): 163-166.

Singh, S. P and H. N. Singh. 1979. Genetic divergence in okra (L. moerch) Indian J. Hotr. 36 (2): 166-170. 